\title{
Threat to business activity in times of the pandemic
}

\author{
HALINA CHŁODNICKA \\ Department of Finance, Banking and Accounting \\ Rzeszow University of Technology \\ Al. Powstancow Warszawy 12, Rzeszow 35-959 \\ POLAND
}

\begin{abstract}
The accuracy of economic decisions depends on the quality of financial information, coming mainly from financial statements prepared by economic and other entities. In times of the pandemic, the threats to continuing economic activity appear to be greater. Hence, there is a need to develop hedging instruments. Good information could protect many entities from the risk of bankruptcy. Such entities need transparent, easy to calculate indicators informing them about the impending crisis. When analysing exposures in financial statements, one can see that their volume is constantly increasing and recipients complain about the decreasing readability. The aim of the article is to create such information which would allow the entrepreneur to react quickly and dynamically to the weakening of his activity to create simple indicators to assess the situation, to separate items on the balance sheet, which would pose a risk of bankruptcy
\end{abstract}

Key-Words: threat to activity, symptoms of threat, pandemic.

Received: August 6, 2020. Revised: December 8, 2020. Accepted: January 6, 2021. Published: January 11, 2021.

\section{Introduction}

Risk plays a dominant role in everyday life as it exists in all areas of human activity. One cannot avoid it as it involves uncertainty about the future that cannot be predicted accurately or controlled. Risk is of special importance in business activities, where entities deal with it on a daily basis [1-6]. It is related to the uncertainty about achieving goals, political, social and technological conditions $[7,8]$. It is especially noticeable in the current economic conditions as it concerns the times of the pandemic. The economic turbulence caused by the COVID-19 epidemic prompts entrepreneurs to undertake increased efforts to save their businesses in the age of a crisis.

Risk and uncertainty are involved in every human activity, and they are sometimes equated. However, it is often assumed in literature that uncertainty exists in a measurable or an immeasurable form, where risk is the former, while uncertainty, in the strict sense, is the latter [9-12]. Risk is determined by two main groups of factors: internal - inherent in the entity conducting business activity, and external - market and political ones. Different classifications of risk appear in literature. The most frequently mentioned include [13]:

- liquidity risk,

- market risk,

- interest rate risk,

- currency risk,

- credit risk

A company is exposed to liquidity risk resulting from financial and contingent liabilities that result mainly from loans that were taken out. Credit risk, in a narrower sense, is understood as a financial loss resulting directly from failure to meet the terms of payment of a loan agreement by the customer. In recent years, banks have been intensively developing their lending activities by introducing new types of loans and improving the procedures of previously granted loans. At the same time, each loan granted by a bank is subject to risk that the borrower will not return the money due.

The most general division of risk involves the sources of its emergence which are divided into external, that is independent of the entity, 
and internal - depending on the quality of the decisions made by the entity $[1,14]$.

The most important external risk factors are:

- the money supply volume,

- the level of central bank interest rates, related to the type of monetary policy pursued,

- exchange rates related to the world economy prosperity [15],

- pandemic, which is a new risk factor

In each unit there are crisis situations threatening the existence of a given entity. The management of the entity should constantly monitor the activities in order to detect the sources of crisis situations. The goal of each economic entity should be early identification of economic risk and undertaking measures aimed at reducing its size. The security can be seen as providing an economic entity with the maximum possible protection, preventing losses or ensuring that losses are compensated for. The bill on special support instruments in connection with the spread of SARS-CoV-2 has entered into force. The act contains new support instruments for companies and also provides for the possibility of launching the so-called financial shield. It gives the Industrial Development Agency (Polish abbreviation ARP) possibility to offer entrepreneurs various instruments to support their current financial liquidity. The support will be granted particularly in the form of loans, guarantees or sureties, as well as leasing or other instruments related to the financing of the conducted business, on market conditions. Nowadays, loans are the most common form of financing investment projects as well as the day-to-day operations of business entities. Financial situation of individual enterprises is very diverse.

The research was conducted by analyzing the financial statement of the balance sheet type of entrepreneurs for 2017, operating in the Podkarpackie province. The methodology of the research was applied by analyzing the subject in terms of the presentation of financial statements, factual analysis and cause and effect analysis. The analysis shows that changes in information are very necessary, especially during times of uncertainty, which are born by the pandemic.

\section{Monitoring of the threat to business activity}

The key aspect when managing the financial resources of an entity is having reliable and credible information about their level, origin or main spending directions. Additional costs in the form of overdue or even penalty interest arise in units with financial instability, when an entity is unable to meet its payment obligations on time, and this is when the costs of financial difficulties arise. Over time, the entity incurs further liabilities and finally is forced to deplete its assets due to a difficult financial situation. This is where insolvency begins and the costs of financial hardship become the costs of bankruptcy [16]. The costs of financial difficulties are often referred to as symptomatic or expected costs of bankruptcy[17].

The symptomatic costs of bankruptcy are often divided into two groups [18]:

- direct costs,

- indirect costs

The first one includes the costs directly related to the appearance of a difficult financial situation, such as costs of the abovementioned additional interest as the first symptoms of financial difficulties, they entail the costs of renegotiating credit agreements, costs related to the valuation of pledged property, court, bailiffs, and, nowadays, costs related to temporary interruption of operations.

The second one, involving indirect costs of bankruptcy, includes specific costs of contracts (agreements) resulting from the volatility of the investment policy and decisions regarding the allocation of its resources. These include lost sales and profits, the costs of financial restrictions applied to enterprises in difficulty and losses due to a reluctance to do business with such an entity [19]. The presented classification of symptomatic costs of bankruptcy is shown in Figure 1. 


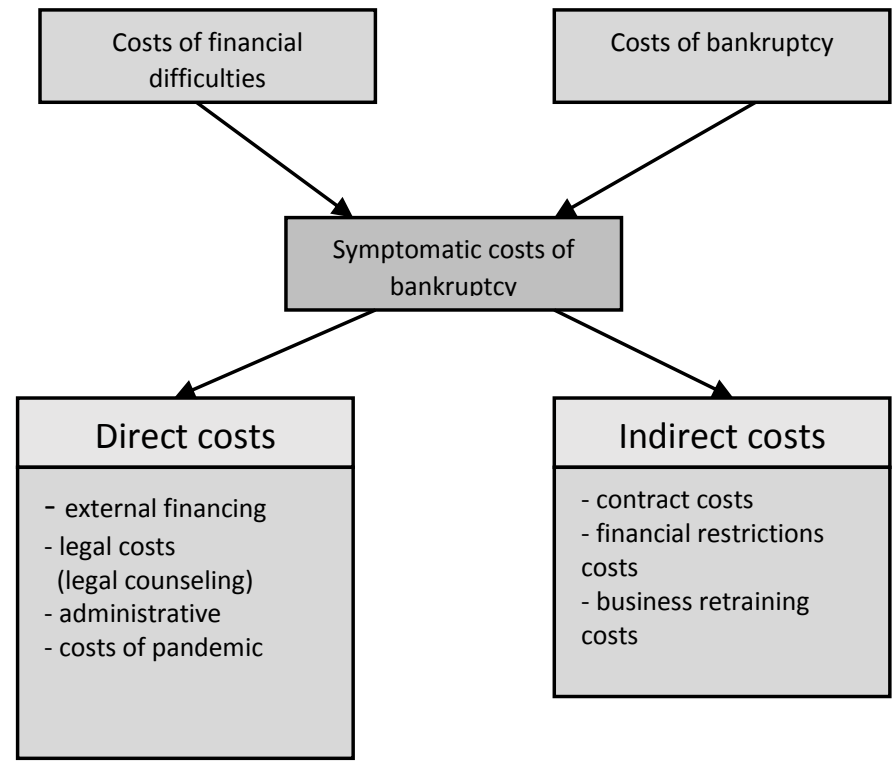

Fig. 1. Classification of symptomatic costs of bakruptcy.

Source: own study

If an entity falls into financial difficulties, many costs that were previously booked were not realized. A modern economic entity is doomed to constant self-improvement. To realize this purpose, it can use a wide range of tools developed by various scientific disciplines and verified in practice. The success of its application depends on understanding the area in which a given tool can be used, getting to know its methodology and, importantly, its correct implementation in practice. Nowadays, something new has emerged - an unpredictable market, jobs, unstable financial family situation, psychological aspects and entrepreneurs facing the risk of bankruptcy. How to monitor such a situation? How to prevent bankruptcy? Many entrepreneurs ask themselves this question.

The so-called "anti-crisis shield" turned out to be a specific tool of financial support for entrepreneurs. It is a bill passed at the beginning of March that allows the entrepreneurs whose revenues have recently decreased by at least $30 \%$ to apply for support.
The legislative provisions differentiate the amount of support for a given entrepreneur depending on the level of decline in sales of goods or services. The support may amount to a maximum of $50 \%, 70 \%$ or $90 \%$ of the amount constituting the sum of salaries of individual employees plus social security contributions (Polish ZUS). However, one should keep in mind that the maximum amount of support will not exceed 50\%, 70\% and $90 \%$ respectively of the minimum wage, increased by the employer's social secutiry (Polish ZUS) contributions. Microentrepreneurs may apply for similar support. They can also apply for a one-time, favourable-rate loan of PLN 5,000, which, however, must be returned within 12 months. Such aid depends on each state individually. The time of the pandemic is getting longer, entrepreneurs are failing, which is very visible on the market. This support does not help, so tools to monitor such situations on an ongoing basis should be created, so that one can react, and especially protect oneself. Chart 1 presents the number of companies with operating difficulties.

Chart 1. Number of companies with operating difficulties

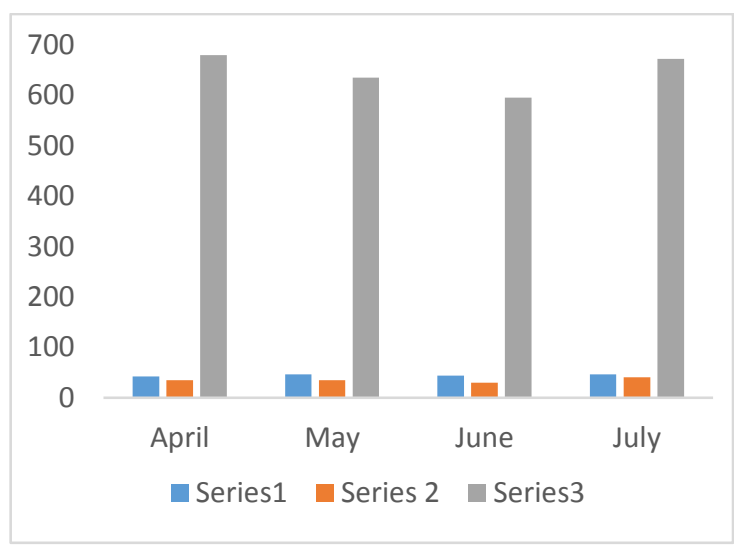

Source: own study

Series 1- bankruptcy of companies

Series 2- restructuring of companies

Series 3 - consumer bankruptcies

April - 42 company bankruptcies, 35 restructuring proceedings and 680 consumer bankruptcies 
May - 46 company bankruptcies, 35 restructuring proceedings and 635 consumer bankruptcies

June - 44 company bankruptcies, 30 restructuring proceedings and 595 consumer bankruptcies

July - 46 company bankruptcies, 41 restructuring proceedings and 672 consumer bankruptcies

Bankruptcy may be announced by insolvent persons, i.e. those who do not fulfill their obligations. It is presumed that a debtor is insolvent if he has not paid his obligations for more than three months (Art. 10 and 11 of the Bankruptcy Law). The solution is to create a supplement to the financial statement that monitors the risk for business activity, maybe create the so-called operating surplus - the difference between income and current expenses (allows one to service e.g. debt, e.g. the costs of a pandemic and other such occurence)? How to protect oneself? The next chapter will answer this question.

\section{Tools for monitoring the threat of bankruptcy}

How to protect oneself? That is a question that anyone doing business today would like to know. According to the author, creating the so-called operating surplus, i.e. transferring part of the profit, is difficult but provides one with the feeling of security. Such amount will be deposited on a special account. The best incentive to do so would be to exempt such measures from taxation. This would be an opportunity to secure the activities of a lot of entrepreneurs. This would, for instance, allow for debt service, collateral related to the costs of a pandemic or unpredited costs. The Act of 19 June 2020 on interest subsidies to bank loans granted to entrepreneurs affected by COVID-19 and on simplified proceedings for approval of an arrangement related to the occurrence of COVID-19 was published on the same day in the Official Journal (Official Journal of 2020, item 1086), with its regulations entering into force on June 24th. However, according to the author, various methods of state aid are not a complete guarantee for those conducting business, as loans and credits, even the interest-free ones, must be returned. Non-returnable assistance is risky as well, being more of a psychological factor, which may also result in a threat to continuing the business activity. The set of economic forecasting methods is currently very rich and includes many methods that come from various scientific disciplines. All these threats, symptoms of bankruptcy occur in unpredictable situations, such as the time of a pandemic, so why not create a kind of security - let's call them threat costs, i.e. eliminate the items that lead to the deterioration of the financial situation of the individual.

All this can lead to bankruptcy, so it is better to react, observe and monitor earlier. Bankruptcy costs can be defined as a decrease in the economic benefits in a given reporting period or a future disbursement of the economic benefits of a reliably determined value by an entity, causing deterioration of the economic entity's financial condition, resulting in additional burdens determining the future process of bankruptcy [20-23]. However, how do we define the costs resulting from a pandemic which are also a threat of bankruptcy, as unpredictable, depending on the course of the disease. The question that arises is how to anticipate, how to protect ones against such situations. As mentioned earlier, "economize", monitor with the use of appropriate tools, e.g. separation of records, as presented in Table 1.

Table 1. Presentation of data with seperation of financial difficulties. in thousands of PLN

\begin{tabular}{|l|c|c|c|c|}
\hline Assets & F1 & F2 & F3 & F4 \\
\hline Fixed assets & 1974 & 857 & 320 & 82 \\
\hline Current assets & 3373 & 4428 & 1757 & 2850 \\
\hline Total assets & 5348 & 5285 & 2077 & 2932 \\
\hline $\begin{array}{l}\text { Symptoms of } \\
\text { threats from } \\
\text { receivable } \\
\text { sreceivable } \\
\text { write-downs }\end{array}$ & 1546 & 1474 & 650 & 1580 \\
\hline
\end{tabular}




\begin{tabular}{|c|c|c|c|c|}
\hline Liabilities & F1 & $\mathrm{F} 2$ & F3 & F4 \\
\hline Equity capital & 2184 & 4358 & 1494 & 1065 \\
\hline $\begin{array}{l}\text { Liabilities and } \\
\text { reserves }\end{array}$ & 3164 & 927 & 583 & 1866 \\
\hline Total liabilities & 5348 & 5285 & 2077 & 2932 \\
\hline $\begin{array}{l}\text { Symptoms of } \\
\text { threats from } \\
\text { liabilities: } \\
\text { reserve } \\
\text { liabilities } \\
\text { secured on } \\
\text { assets long- } \\
\text { term liabilities }\end{array}$ & 3164 & 927 & 507 & 1865 \\
\hline $\begin{array}{l}\text { - short-term } \\
\text { liabilities: }\end{array}$ & 2847 & 875 & 507 & 1272 \\
\hline unpaid wages & 33 & - & 28 & 29 \\
\hline $\begin{array}{l}\text { public-law } \\
\text { liabilities }\end{array}$ & 68 & 241 & 47 & 66 \\
\hline trade payables & 2728 & 622 & 428 & 1155 \\
\hline other liabilites & 17 & 12 & 2 & 20 \\
\hline
\end{tabular}

Source: own study

in practice. Nowadays, something new has

In Table 1, the symptoms of threat do not include accruals, assuming that these values will not generate a threat to the activity. This table presents receivables and liabilities that are overdue and may cause payment congestion, and this will generate further difficulties. Perhaps it is worth isolating such symptoms of danger, assessing them and reacting earlier. Times have changed, so companies should also follow the forced changes, and those creating reporting information should improve such information. Entrepreneurs should monitor (all) their liabilities on an ongoing basis to assess their condition and create various collateral. In such uncertain conditions, current liabilities could become overdue liabilities overnight. Table 2 attempts to create some crucial tools for rapid monitoring of the threat to business activities.

Table 2. Indicators warning about threats to continuing activity

\begin{tabular}{|c|c|c|c|c|c|}
\hline $\begin{array}{l}\text { N } \\
\text { o. }\end{array}$ & $\begin{array}{l}\text { Indica } \\
\text { tor }\end{array}$ & $\mathrm{F} 1$ & F2 & F3 & $\mathrm{F} 4$ \\
\hline 1. & $\begin{array}{l}\text { Total } \\
\text { liabilit } \\
\underline{\text { ies }} \\
\text { Total } \\
\text { assets }\end{array}$ & $\begin{array}{l}\frac{3163199}{5348724} \\
59 \%\end{array}$ & $\begin{array}{l}\frac{927072}{5285475} \\
18 \%\end{array}$ & $\begin{array}{l}\frac{583427}{2077904} \\
=28 \%\end{array}$ & $\begin{array}{l}\frac{1866750}{2932743} \\
=64 \%\end{array}$ \\
\hline 2. & $\begin{array}{l}\text { Sympt } \\
\text { oms } \\
\text { of } \\
\text { threat } \\
\text { s from } \\
\text { liabilit } \\
\underline{\text { ies }} \\
\text { Curre } \\
\text { nt } \\
\text { assets }\end{array}$ & $\begin{array}{l}\frac{3164199}{3373845} \\
94 \%\end{array}$ & $\begin{array}{l}\frac{927072}{4428411} \\
21 \%\end{array}$ & $\begin{array}{l}\frac{507181}{1757334} \\
29 \%\end{array}$ & $\begin{array}{l}\frac{1865247}{2850372} \\
65 \%\end{array}$ \\
\hline 3. & $\begin{array}{l}\text { long- } \\
\text { term } \\
\text { liabilit } \\
\underline{\text { ies }} \\
\text { short- } \\
\text { term } \\
\text { liabilit } \\
\text { ies }\end{array}$ & $\begin{array}{l}\frac{316666}{2843533} \\
11 \%\end{array}$ & $\begin{array}{c}\frac{0}{875772} \\
0 \%\end{array}$ & $\begin{array}{c}\frac{0}{507181} \\
0 \%\end{array}$ & $\begin{array}{l}\frac{592763}{1272483} \\
47 \%\end{array}$ \\
\hline 4. & 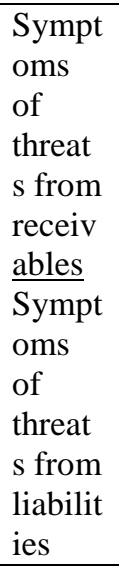 & $\begin{array}{l}\frac{1546592}{3164199} \\
49 \%\end{array}$ & $\begin{array}{l}\frac{1474829}{927072} \\
159 \%\end{array}$ & $\begin{array}{l}\frac{650663}{507181} \\
128 \%\end{array}$ & $\begin{array}{l}\frac{1580119}{1865247} \\
85 \%\end{array}$ \\
\hline
\end{tabular}

Source: own study

When analyzing subsequent indicators and cases, indicator 1 for companies F1, F2, F3 is what should attract attention, probably under normal economic conditions they would not be such a threat yet, but in the present times of uncertainty, they should attract attention to the significant volume of liabilities and look for opportunities to settle them. The analysis of indicator 2 also confirms that, where the value of liabilities for company $\mathrm{F} 1$ is $94 \%$, i.e. the 
value of liabilities is almost equal to current assets, but nowadays even selling off assets is difficult. In other cases, the situation is not that difficult, but in the case of company $\mathrm{F} 4$ it is $64 \%$, so the trader should stay alert. What deserves attention is the 4th indicator, which is the ratio of receivables to liabilities. In virtually every case, the ratio is high, which would mean that it is beneficial that the assets exceed the liabilities, but it may be misleading information. During the pandemic, many companies have declared bankruptcy (Figure 1 ), so many debts may not be recoverable. Therefore, one should monitor and possibly use tools to recover debts, and this will help in paying off one's liabilities. In virtually each of these entities there are obligations towards employees and public offices. The current time of the pandemic has caused downtime in business. Short term liabilities seem to be a substantially greater threat. With the lack of turnover, even these short deadlines begin to overlap and payment gridlocks appear. That is why entities should pay particular attention to payment of receivables and short-term liabilities because this can affect other entities. Over two million Poles cannot cope with overdue debt.

\section{Conclusion}

The conducted empirical studies have shown the following:

- entities delay their interest in payment gridlocks, increasing liabilities, and debts unpaid by entrepreneurs, whereas in many cases an earlier reaction would help to maintain principle of continuing the business activity,

- therefore, all information about the symptoms of a threat to the activity should be displayed - as a non recorded piece of information,

- responsible managers should not be afraid of such information that will save the future of the company, it would be inside information, but would allow the application of security measures,
- the identification of the symptoms of danger will allow a quick reaction and preventive measures to be taken before bankruptcy

- The conclusion is drawn that the symptoms of threat are mainly related to the threat of loss of financial liquidity, as the table shows, the more liabilities, the greater the symptoms.

- A major advantage of such an approach to assessing the risk of threat to business continuity is the simplicity of the indicators used in assessing the situation of the entity

Continuing of the business activity does not exclude the existence of serious threats to it, which the manager is obliged to inform about. It is also crucial that the identification of these threats is clear and simple for small and medium-sized entrepreneurs.

\section{References}

[1] Wójciak, M. (2007). Metody oceny ryzyka kredytowego, Polskie Wydawnictwo Ekonomiczne, Warszawa, pp 11-12.

[2] Cunat, V. (2007). Trade credit: Suppliers as debt collectors and insurance providers. Rev. Financ. Stud. 20, pp. 491-527.

[3] Martínez-Sola, C.; García-Teruel, P.; Martínez-Solano, P. (2014). Trade credit and SME profitability. Small Bus. Econ.Springer, 42, pp. 561-577.

[4] Tinoco, M,H.; Wilson, N. (2013). Financial distress and bankruptcy prediction among listed companies using accounting, market and macroeconomic variables, International Review of Financial Analysis, Volume 30, December 2013, pp.394-419

[5] Zimon, G. An assessment of the strategy of working capital management in polish energy companies.Int. J.Energy Econ. Policy2019,9, 552-556

[6] Zimon, G. Influence of group purchasing organizations on financial situation of Polish SMEs.OeconomiaCopernic.2018,9, 87-104. [CrossRef] 
[7] Zimon, D.; Zimon, G. (2019). The impact of implementation of standardized quality management systems onmanagement of liabilities in group purchasing organizations. Qual. Innov. Prosper.2019,23, 60-73.

[8] Chłodnicka, H.; Zimon G. (2020). Bankruptcu Risk Assessment Measures of Polish SMEs, WSEAS Transactions on Business and Economics, Volume 17, 2020, pp. 14-20.

[9] Flejterski S., Pluskota P., Szymczak I., (2005). Instytucje i usługi doręczeniowe na rynku finansowym, Difin, Warszawa 2005, s. 9-10.

[10] Huang, L.; Ying, Q.; Yang, S.; Hassan, H. (2019). Trade Credit Financing and Sustainable Growth of Firms: Empirical Evidence from China. Sustainability, 2019,11, 1032

[11] Walasek R., Zimon, G.(2020). The Analysis of Financial Liquidity Management in Small Transport Enterprises During the COVID 19 Pandemic - Case Study of Poland, WSEAS Transactions on Business and Economics, Volume 17, pp. 786-795

[12] De Almeida, J, Eid Jr. W . (2014). Access to finance, working capital management and companyvalue: Evidences from Brazilian companies listed on BM\&FBOVESPA.Journal of Business Research67: pp. 924-34.

[13] Gospodarowicz A., Możaryn H. (1998). Identyfikacja i szacowanie ryzyka kredytowego, Wydawnictwo Akademii Ekonomicznej we Wrocławiu, Wrocław pp. 15-17.

[14] Zimon, G., Zimon D. (2019).The Impact of Quality Management Systems on Financial Liquidity in Companies in Group Purchasing Organizations, WSEAS Transactions on Business and Economics, Volume 16, 2019, pp. 163-170.

[15] Gątarek, D., Maksymiuk, R., Krysiak, M., Witkowski, Ł. (2001). Nowoczesne metody zarządzania ryzykiem finansowym , WIG-Press, Warszawa 2001, s.14.

[16] Ross, S. A., Wester R. W., Jordan B. D. (1991). Fundamentals of Corporate Finanse, Irwin, Homewood, 1991 r., s. 488
[17] White, M. J., (1989). The Corporate Bankruptcy Decisions, Journal of Economic Perspective" (vol 3), nr 2/1989

[18] Baxter, N., Laverage, L. (1967). Rish of Ruin and the Cost of Capital, Jurnal of Finance, 1967 r., nr. 22;

[19] Chłodnicka, H. (2014). Sprawozdanie finansowe a pomiar efektów działalności przedsiębiorstwa w zagrożeniu kontynuacji działania, Wydawnictwo Uniwersytetu Ekonomicznego we Wrocławiu, Prace Naukowe Uniwersytetu Ekonomicznego we Wrocławiu, Wrocław 2014, s.87-101.

[20] Prawo Upadłościowe Dz.U. 2019 r., poz. 1802

[21] Jensem, M. C., Snnnith, C. W. (1984). The Modern Theory Corporate Finance, Mc Graw-Mill Book Company 1984 pp. 10-12.

[22] J. B. Warner. (1977). Bankruptcy, Absolute Priority and the Princing of Rissy Debt Clains, Jurnal of Financiel Ekonomimcs, May. pp. 14-21

[23] Dalci, I.; Ozyapici, H. (2018). Working capital management policy in health care: The effect of leverage. Health Policy, Volume 122, Issue 11, November 2018, pp. 1266-1272.

\section{Contribution of individual authors to the creation of a scientific article (ghostwriting policy)}

\section{Author Contributions:}

Halina Chłodnicka- responsible for organizing and conducting the study, systematizing data, reviewing the literature, developing content, analysis, statistics, systematizing data, content development.

\section{Creative Commons Attribution License 4.0 (Attribution 4.0 International, CC BY 4.0)}

This article is published under the terms of the Creative Commons Attribution License 4.0 https://creativecommons.org/licenses/by/4.0/de ed.en US 